\title{
Diagnóstico e utopia
}

\section{FÁBIO WANDERLEY REIS}

\begin{abstract}
C REIO QUE A DISCUSSÃo sobre a sobrevivência das idéias expressas sinteticamento no Manifesto Comunista pode se basear com proveito na distinção de três aspectos: o diagnóstico dos processos que Marx e Engels observavam, o projeto de ação política mais ou menos imediata e a utopia ou o ideal orientador.
\end{abstract}

O aspecto de diagnóstico é aquele que, especialmente no referente à dinâmica geral do capitalismo, mais parece justificar comentários admirados na atualidade pela nitidez e vigor com que nele se antecipam traços os quais os fenômenos ligados à globalizaçăo dos nossos dias só fizeram intensificar. Não obstante os erros quanto à previsão das consequiências dessa dinâmica sobre a estrutura de classes (a pauperizaçáo e a polarizaçáo de classes), dois dos traços mencionados podem talvez ser destacados: o caráter revolucionário da economia capitalista, cuja lógica a leva à permanente inovaçáo tecnológica e a subverter a cada dia as relaçóes de produçáo estabelecidas; e os desdobramentos dessa lógica no plano das formas de organizaçáo político-territorial, por um lado, ajudando a plasmar o Estado-nação moderno como espaço privilegiado das transaçôes econômicas que suplanta a fragmentação e o paroquialismo tradicionais; por outro, criando um mercado internacional ou transnacional que se afirma vigorosamente desde os primórdios do capitalismo moderno. Em belo volume recente, $O$ longo século $X X$, que coloca em perspectiva singularmente clara a globalização atual, Giovanni Arrighi retoma análises clássicas que remontam a Marx para mostrar a crescente ampliação da escala em que economia e política se articulam.

Esse aspecto de diagnóstico pretende servir de base objetiva para o projeto político, que é naturalmente o projeto de implantação revolucionária do socialismo e da ditadura do proletariado. Posto à prova na experiência (e no colapso) do socialismo real, tal projeto se encontra claramente envelhecido e superado pelo movimento da história. Não somente se desvendou a ilusão de se pretender recorrer à ditadura para construir um socialismo verdadeiro, que resgatasse a fundamental inspiração humanista e democrática do movimento socialista; de fato, o socialismo real terminou por ver comprometida a viabilidade e a eficiência econômicas mesmo da organizaçáo autoritária presumidamente provisória - em especial, ironicamente, nas condiçóes de exacerbação do 
mercado globalizado e duramente competitivo que o Manifesto aponta e antecipa.

Por outro lado, o apego ao projeto político revolucionário associa-se com equívocos a serem encontrados quanto à dimensão política do próprio aspecto de diagnóstico que consideramos em primeiro lugar. O que temos aqui é uma teoria política nitidamente distorcida, vinculando a idéia de poder político exclusivamente ao poder de uma classe para oprimir outra, permitindo a pretensão de que, na sociedade sem classes supostamente passível de ser descrita como "vasta associação da naçáo como um todo", o poder público perderia o seu caráter político. Daí a fantasia de substituir a política pela mera administração das coisas, acoplada ao rechaço do aparato institucional do Estado liberal como simples instrumento dos negócios da burguesia. $O$ foco exclusivo na ação revolucionária bloqueia a percepçáo da possibilidade de que o amadurecimento do capitalismo produzisse, em vez da ruptura, as condiçóes para o amadurecimento da própria democracia e para o compromisso institucional em que se destacaria o componente social da cidadania, ao lado de seus componentes formais correspondentes aos direitos civis e políticos, e no qual a própria dimensão contraditória do capitalismo se veria institucionalizada. Em particular, quando posta em confronto com a espetacular derrocada do socialismo real, essa saída social-democrática revelar-se-ia a única verdadeiramente estável - e talvez a via por meio da qual se poderia aspirar à aproximaçáo gradual das condiçóes entrevistas na utopia.

A este ponto, porém, a avaliaçáo se contorce, pois a dinâmica econômico-tecnológica recente sintetizada no rótulo de globalização compromete também a solução social-democrática. Propiciando a intensificação da competiçáo, essa dinâmica coloca objetivamente em xeque os componentes daquela solução que se consagraram no pós-guerra (o keynesianismo, o Estado de bem-estar e as organizaçóes sindicais conjugados em estruturas neocorporativas), e termina por engendrar uma nova perspectiva filosófica na qual os direitos sociais institucionalmente assegurados de outrora sáo abandonados ao jogo flexivel do mercado em que alguns ganham e outros perdem. Os efeitos perversos daí resultantes, sob a forma de exclusão social e incremento da desigualdade, deixam claro que se abre mão do próprio compromisso institucional e se coloca em risco a democracia mesma. Combinados ao potencial de crises que se dá na financeirização do capitalismo mundial, tais efeitos ameaçam corroborar, ao cabo, as apostas socialmente convulsivas do Manifesto. E fala bem do internacionalismo de Marx e Engels o fato de que as respostas apropriadas certamente não viráo dos meros Estados nacionais, incapacitados eles próprios nos processos correntes. 
Resta o aspecto do ideal ou da utopia. A visão positiva do caráter revolucionário da burguesia, a qual marca algumas das passagens mais famosas do Manifesto, associa-se com algo que tende a ser relegado ou omitido nas discussóes das idéias de seus autores: a visáo positiva do próprio mercado como espaço no qual se realiza o valor da autonomia individual, visão esta que surge com nitidez, por exemplo, em Resultados do processo imediato de produçáo e se reafirma em outros termos em passagens igualmente célebres da Ideologia alemã, carregadas de forte individualismo. Conjugadas ao óbvio solidarismo que se afirma na visão do homem sociabilizado e capaz de se alçar acima dos egoísmos vis que fazem "derreter no ar tudo que é sólido", essas perspectivas trazem à utopia marxista algo que poderia ser visto como peculiar combinação de realismo e sonho - ou, mais adequadamente, como conjugação de dois valores que se articulam tensamente: o da autonomia, ou da busca individual desembaraçada de fins ou interesses definidos autonomamente, e o valor da solidariedade, ou da convergência livre de violências. Ora, a articulação tensa desses mesmos valores é característica da própria noçáo contemporânea de cidadania, em que o ideal moderno e liberal de autonomia e capacidade de autoafirmação se combina com o ideal clássico de civismo virtuoso e solidário, do qual os direitos sociais e a concepçáo de um Estado capaz de garantir proteção social universal são expressão. Também por este aspecto, sem dúvida, as idéias de Marx e Engels se encontram vivas. E, se as condiçóes do mundo globalizado e integrado trazem formidáveis ameaças novas às aspirações af contidas, elas representam também o desafio - passível de ser visto de maneira positiva, além de objetivamente inescapável, se não nos quisermos entregar a determinismos cegos - de tratar de realizar tais aspiraçóes na escala inédita do planeta como tal.

Fábio Wanderley Reis é professor da Universidade Federal de Minas Gerais (UFMG). 